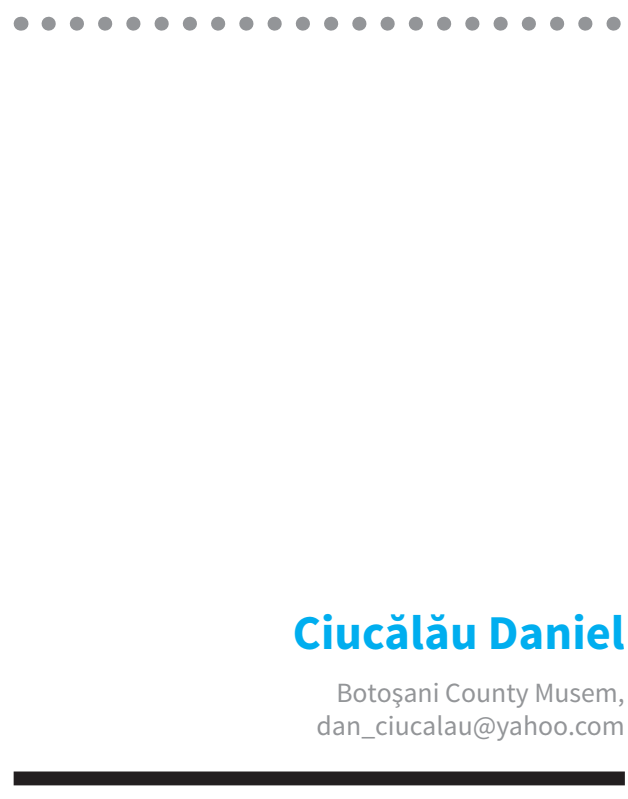

DOI: http://dx.doi.org/10.14795/j.v1i1.10

ISSN $2360-266 \mathrm{X}$

ISSN-L $2360-266 X$

\section{ABOUT PRISMATIC ANTLER PENDANTS FROM SÂNTANA DE MUREŞ- CERNJACHOV CULTURE}

\begin{abstract}
Numerous influences can be noticed within Sântana de MureşCernjachov culture. They are targeting not only the material aspects of daily life but the spiritual life of its different ethnic components, as well. A series of prismatic pendants made of antlers decorated with circles century are documented in the $4^{\text {th }}$ century AD graves of women and children. Some scholars, such as J. Werner and I. Ioniţă have regarded them as replicas of type Herkuleskeule amulets. They were adopted in the Germanic world as symbols of the god Thor/Donau. This work presents such type of amulets discovered in some of the $4^{\text {th }}$ century AD necropolises that underwent research in Romania and the Republic of Moldova.

Keywords: Goths, prismatic antler pendants, religion, cemeteries, Sântana de Mureş-Cernjachov culture
\end{abstract}

$\mathbf{R}$ oman, Germanic, Sarmatian and Dacian influences may be identified within the Sântana de Mureș-Cernjachov culture. The cohabitation in a common area of such diverse groups of populations had influenced not only economic and social aspects of their daily life, but also their religious beliefs. If, on the material aspects of this culture Archeology has provided a huge amount of information that allowed the classification and dating of some discovered materials (ceramics, tools, jewelry etc.), dates referring on the spiritual life are fewer and therefore are much less presented in specialty works. Researches carried out on the cemeteries of culture Sântana de Mureș-Cernjachov offers a much diversified picture of the funeral rites and rituals practiced in the fourth century by the polytheistic populations which were living at the border of the Roman Empire. In many of the graves, the dead were deposited along with a rich inventory consisting of earthenware or glass and a number of objects that have belonged to their everyday life (jewelry, weapons, tools). Among the personal belongings found we can distinguish amulets, whose presence should be judged not only aesthetically but also in the terms of the relationship that their owners had created with supernatural world. They are made of different materials and they are present in a variety typological. In the category of those made from animal horns we can include a series of prismatic shaped pendants, considered by some researchers as barbaric versions of the amulets of Herkuleskeule type, very 
common in the Roman Empire, especially since the third century $^{1}$. Joachim Werner had demonstrated at mid- last century, in an article well documented that these pendants are of Germanic origin, representing the symbols of the god Thor/Donar from Norse mythology that has attributes similar to those of Hercules. ${ }^{2}$

Prismatic pendants are found scattered throughout the culture Sântana de Mureş-Cernjachov, as confirmed by the finds from Romania: Miorcani ${ }^{3}$, Mihălăşeni ${ }^{4}$, Hăneşti ${ }^{5}$, Târgşor ${ }^{6}$, Bârlad-Valea Seacă ${ }^{7}$, Spanţov, Olteni ${ }^{8}$, Republic of Moldova: Brăviceni ${ }^{9}$, Ukraine: Kertchi ${ }^{10}$. There are some exceptions, such as from Budeşti, Republic of Moldova ${ }^{11}$ or Leţcani, Romania ${ }^{12}$, that could be the result of a careless research of the material discovered - often these artifacts can be destroyed during the cremation of the deceased - or lack in the community of the people who believed in their protective power. In this sense we can make an observation that also applies to other types of amulets, related on the fact that are very few graves which contain prismatic pendants . Taking for example only three large cemeteries researched in Romania we can see that at Mihălăşeni only in 7 graves from 520 the dead were deposited with such amulets, in BârladValea Seacă - these were found in 7 from the total of 547 graves and in 5 from 256 at Târgsor. The presence of prismatic antler pendants is signaled further than the Sântana de Mureş-Cernjachov culture area, reaching across Central and northern Europe ${ }^{13}$. This fact prompted M. Kazanski to include them in the category of objects that owes their spreading the influence of the Goths in the Germanic world, alongside with round handle combs, glass cups decorated by polishing or shells snails reused as pendants ${ }^{14}$.

Such pendants were made from animal horns, most probably from antlers, some even keeping slightly curved shape of the material from which they has been processed. In the upper part, narrowest, they have a hanging hole that served to hang them by belt or clothing. Their size varies from 3 to $7 \mathrm{~cm}$. Depending on their shape have been identified two categories. The first consists of pendants square in section and is a type version 6 of the classification made by O.L. Şovan ${ }^{15}$ or Type 6 , in the one of V. Vornic and L. Ciobanu ${ }^{16}$. These are the most common and can be found at Mihălăşeni, Brăviceni, Târgşor Spanţov, Kertchi etc. A second category is rarer and consists of rectangular pendants, almost flat. In the classification made by O.L. Şovan they represent version $b$ of type 6 of the prismatic pendants ${ }^{17}$. At Mihălăşeni were discovered

\footnotetext{
${ }^{1}$ POPOVIČ, 1998

${ }^{2}$ WERNER 1964, 176-199

${ }^{3}$ IONITĂ, 1974

${ }^{4}$ ȘOVAN, 2005, 161

${ }^{5}$ ZAHARIA/ZAHARIA/SOVAN 1993

${ }^{6}$ DIACONU 1964, 104

${ }^{7}$ PALADE, 2004, 213

${ }^{8}$ PALADE, 2004, 213

${ }^{9}$ VORNIC/CIOBANU 2010

${ }^{10}$ KAZANSKI 2009, 19

${ }^{11}$ VORNIC 2006

${ }^{12}$ BLOŞIU 1975

${ }^{13}$ VERLAG 1954 14, POPOVIČ 1998

${ }^{14}$ KAZANSKI 1991, 58

${ }^{15}$ ȘOVAN 2005, 161

${ }^{16}$ VORNIC/CIOBANU 2010

${ }^{17}$ ȘOVAN 2005, 161
}

six in number and at Olteni only two ${ }^{18}$. In the tomb 318 from the necropolis researched by O.L. Şovan ${ }^{19}$ it has been identified a specimen having a less common form for the culture Sântana de Mureş-Cernjachov (photo 1). It has a rounded bottom, unlike other pendants from the same class, which are composed of straight lines, and is decorated with three groups of concentric circles on each side. Its shape is similar to that of another artefact, made of thin gold foil, with the face grainy and a smooth reverse discovered at Obreja $(A l b a)^{20}$ which could represent the Hercules knot $^{21}$.The pendant found at Mihălăşeni is a hybrid form, which combines the specific German decor and a characteristic form of the Greco-Roman ornaments. Relations between this community from Upper Jijia Plain and the Roman world were pretty close in the fourth century, as evidenced by the large number of import artifacts discovered in the inventory of the graves. Moreover, in the grave 123 of the same cemetery were found three glass pendants, unique in the North Carpathian space, with Christian symbols, which, again, underlines the diversity of the ties with the Roman world ${ }^{22}$.

The specific decor of the prismatic pendants, as mentioned in the above lines, consists of circles, sometimes concentric, made by incision and with a dot in the middle. In the case of the ones with square section, the decor is deployed on three or four sides, while the rectangular ones are decorated only on two parts (I met an exception to a specimen from Mihălăşeni, discovered in tomb $477^{23}$, which has decoration on the all sides - Photo 2). As Gh. Diaconu noticed ${ }^{24}$, this type of decor is shared with the combs found in the fourth century tombs of culture Sântana de Mureş-Cernjachov, which could suggest a link between the symbolisms of the two types of objects. The circles are often placed simply one under other, but there are variants such as drawing two circles on several rows ${ }^{25}$ or their enrollment in a frame ${ }^{26}$.

Prismatic pendants were discovered, located between the femurs and between tibias, singly or in pairs, in women and children graves. Given that this type of ornaments has a hole for hanging, we can assume that they were bound by the strap or by robes. Although it is difficult to establish a rule regarding the number of pendants worn by a person, it was noticed that in the cremation graves they appear one each and in the inhumation tombs may occur more. Still referring to how these pendants could be worn, at Mihălăşeni, in the grave 319 , we observe a less common situation. The tomb belongs to an elderly woman (50-55 years) Mediterranean type with Nordic influences. Between skeleton's femurs were discovered more objects (6 blue glass beads, two prismatic pendants, a fragment of a bronze object with hole at one end, a circular ring of bronze, two fragments of seashells Cypreea with hole for hanging) which O.L. Şovan had considered to have been submitted in a cloth bag. ${ }^{27}$ The situation is

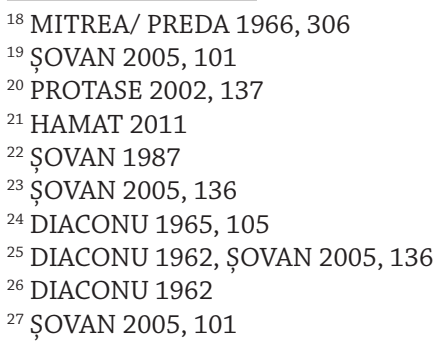


similar with the one from the tomb 150 in the necropolis of Wecklige, Poland, where it was discovered an elderly woman (60 years), submitted together with a rich inventory which had included a bag of amulets containing four Kaurishellpendants fastened at a bronze-band, a bear claw mounted in bronze-mounting, three big shield-formed and flattened amber-beads, nicely worked and mounted in bronze- rings, who were decorated with so-called magical rosettes, still more big amber-beads of a flattened shape, nice multicolored glass beads and a pearl of bronze. Jerzy Okulicz -Kozaryn, the researcher of this necropolis, believes that the person buried here is a priestess-oracle ${ }^{28}$. The presence of a person with such a rank buried in the cemetery from Mihălăşeni could not be excluded, given that the size, richness and variety of inventory found in it most likely belonged to a major settlement in the Moldavian Plateau.

The cult of Hercules reaches its peak in Roman Empire during the reign of Commodus, a great admirer of the hero, who had minted the first coins with the inscription Hercules Romanus, and later Hercules Commodianus. Driven by imperial cult the followers of this god grew in number, which explains the great popularity and the production of a large number of ornaments and amulets with the motif Hercules knot, both during the third century and the first part of the next one ${ }^{29}$. Prismatic antler pendants are present in the area of Sântana de Mureş-Cernjachov culture since the fourth century. Thus, in a tomb excavated in 1867 at Kertci, was found a specimen along with a coin minted in times of Rescouporis VI and Thothorse $(303-308 / 309)^{30}$ and at the necropolis of Mihălăşeni the appearance and spread of this type of pendants occur in stages II-III of its internal chronology (first half of the fourth century) ${ }^{31}$ It is the same period in which contacts of Gothic tribes with the Roman world, violent or peaceful, have intensified. Under the influence of war prisoners, of the refugees or the Goths who have served in the Roman army, this pendants, symbols of a god with similar attributes to those of one of their god, enter in the barbaric world and begin to spread more and more, reaching the shores of the North Sea in Schleswig and Holstein and even west of $\mathrm{Elba}^{32}$. Prismatic antler pendants are spread uniformly throughout the culture Săntana de MureşCernjachov, which might suggest a common belief in their protective power. The presence of a priestess, as the one from Mihălăşeni, means the existence of a cult well organized. In Germanic tribal societies the priestesses are well confirmed in the written sources, which show that they often played a deciding role for the tribe and were highly revered. I am referring here to the famous Veleda, the leader of the Bructs according to the telling of Tacitus ${ }^{33}$ and the oracle Ganna who were with Masyos, "king" of the Semnones, when they visited the court of Domitianus. ${ }^{34}$ It is difficult to identify the deity that was represented in these pendants, especially in the absence of conclusive written sources referring to

\footnotetext{
$\overline{{ }^{28} \text { NORDGREEN 2004, }} 209$

${ }^{29}$ POPOVIČ 1998

${ }^{30}$ KAZANSKI 2009, 19

${ }^{31}$ SOVAN 2005, 188

${ }^{32}$ VERLAG 1954, 14

${ }^{33}$ Hist.IV. 61, 65: Germ.8

${ }^{34}$ Dio Cassius, 67, 5, 3
}

the beliefs of polytheistic populations which had lived in this area in the fourth century. The opinion of J. Werner and other researchers ${ }^{35}$ is that they are related to the cult of Hercules, the Roman deity who, in the Germanic world, was identified with Donar / Thor. Known from the Edda's songs ${ }^{36}$ mostly as a warrior god who was in eternal conflict with raging forces of nature, personified by the Giants, he also had other attributes, related to the protection of home and family. In the German old religion, god Thor had protected the death - the idea of bringing back to life is found in the myth of the resurrection of his goats, touching them with his magic hammer, Mjolnir, after being sacrificed and eaten. ${ }^{37}$ Moreover, the sign of Thor appears on a number of Viking tomb stones, for the protection of the deceased. The presence of such amulets in tombs belonging to women and children can be linked to the social role of this the symbol in the German community, which was used during other rites, such as the weddings, when it was held in the arms of the woman during the utterance of oaths, or the integration of the new born (it was suspended over the head of the child in moment of recognition by his father $)^{38}$.

\section{ABBREVIATIONS AND BIBLIOGRAPHY}

\section{BLOȘIU 1965}

Bloșiu, C., Necropola din secolul al IV-lea e.n. de la Lețcani (jud. Iași), în Arheologia Moldovei, București 1975, p. 203-280

DAVIDSON 1993

Davidson, H. E., The lost beliefs of Northern Europe, Routledge, Oxford, 1993

DIACONU 1962

Diaconu, Gh., Despre pandantivele prismatice de os din necropola de la Târgșor, în Studii și Cercetări de Istorie Veche, 1962, p. $441-443$

DIACONU 1965

Diaconu, Gh., Târgșor. Necropola din secolele III-IV e.n., București, 1965

HAMAT 2011

Hamat, A., Influenţe elenistice în arta podoabelor din Dacia romană. Motivul „Nodul lui Hercule”, Bibliotheca Historica et Archaeologica Universitatis Timisiensis, XIII, 2011, p. 57-75

IONIȚĂ 1974:

Ioniţă, I., Necropola din secolul al IV-lea de la Miorcani (jud. Botoșani), Cercetări istorice, s.n., V, Iași, 1974, p. 81-92

IONIŢĂ 1982

Ioniţă, I., Din istoria și civilizaţia dacilor liberi, Iași, 1982

MITREA, PREDA 1966

Mitrea, B., Preda C., Necropole din secolul al IV-lea e.n. în Muntenia, Romanian Academy Publishing House, București, 1966

NORDGREEN 2004

Nordgren, I., The Well Spring of the Goths: About the Gothic peoples in the Nordic Countries and on the Continent, iUniverse Inc., Bloomington, 2004

\footnotetext{
${ }^{35}$ IONIŢĂ 1982, 107

${ }^{36}$ The anthology of poems known as The Poetic Edda or the Old Edda and prose compilation made by Snorri Sturluson New Edda are works published in the thirteenth century based on the narrative material created in older age, poems with mythological topic or heroic, composed by unknown authors who lived in a period between 800 and 1100 .

${ }^{37}$ Gilfaginning, 44

${ }^{38}$ DAVIDSON 1993, 101
} 


\section{PALADE 2004}

Palade, V., Așezarea și necropola de la Bârlad-Valera Seacă (sfârșitul sec. al III-lea-A doua jumătate a sec. al V-lea), București, 2004 ȘOVAN 1987

Șovan, O. L., Un mormânt cu medalioane romane de sticlă din necropola de la Mihălășeni (jud. Botoșani), Arheologia Moldovei, XI, București, 1987, p. 227-234.

ȘOVAN 2005:

Șovan, O. L., Necropola de tip Sântana de Mureș-Cernjachov de la Mihălășeni (judeţul Botoșani), Târgoviște, 2005

POPOVIČ 1998

Popović, I.Roman Jewelry in the Form of Hercules Symbols in the Central Balkans, Starinar N S, 1998 (XLIX), p. 77-92

PROTASE 2002

Protase, D., Obreja. Așezarea și cimitirul daco-roman secolele II-IV. Dovezi ale continuităţii în Dacia, Cluj-Napoca, 2001

VERLAG 1954

Verlag, K. W., Formen kreise und Stammesgruppen in Schleswig/ Holstein nach geschlossenen Funden des 3. bis 6 Jahrhunderts, Neumunster, 1954.

VORNIC 2006

Vornic, V., Așezarea și necropola de tip Sântana de MureșCernjachov de la Budești, Chișinău, 2006

VORNIC/CIOBANU 2010

Vornic Vl., Ciobanu L., Obiecte de podoabă descoperite în necropola de tip Sântana de Mureș-Cernjachov de la Brăviceni, Revista Arheologică, S.N., vol. VI, nr. 2, p. 58-79

KAZANSKI 1991

Kazanski, M., Les Goths (I er-VII e siecles ap.J.-C.), Paris, 1991

KAZANSKI 2009

Kazanski, M., Archeologie des peoples barbares, editor Victor Spinei, București-Brăila, 2009

WERNER 1964

Werner, J., Herkuleskeule und Donar-Amulett, in JRGZM 11, 1964, p. 176-199)

ZAHARIA/ZAHARIA/ȘOVAN 1993

Zaharia, E., Zaharia, N., Șovan, O.L., Necropola din secolul al IV-lea d.Hr. de la Hănești (judeţul Botoșani), Arheologia Moldovei XVI, București, 1993, p. 151-189

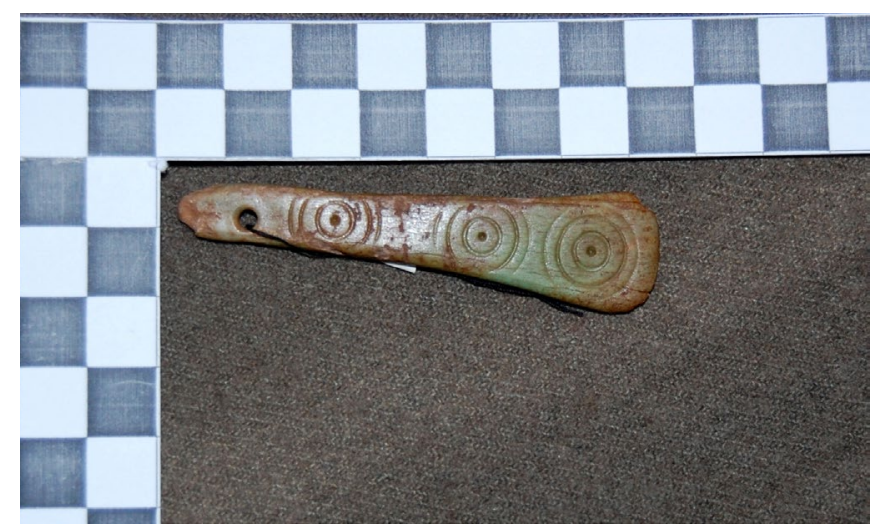

Photo 1. Prismatic antler pendant from

Mihălășeni, Botoșani County, grave 318

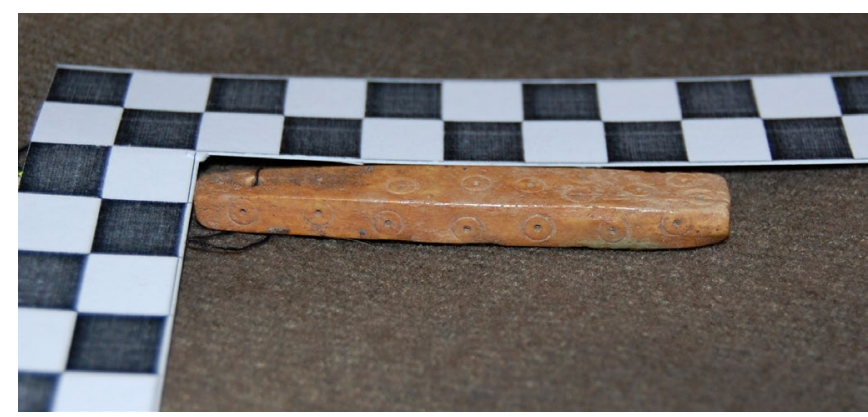

Photo 2. Prismatic antler pendant from Mihălășeni, Botoșani County, grave 477

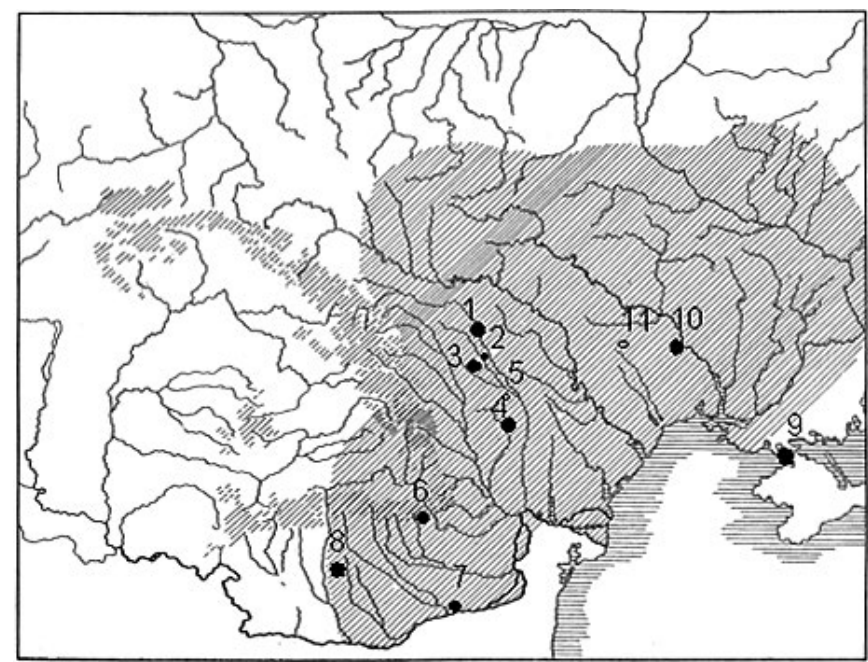

Map of necropolises mentioned in the article

1. Miorcani, Romania, Botoșani County; 2. Mihălășeni,

Romania, Botosani County; 3 . Hănesti, Romania, Botosani

County; 4. Bârlad/Valea Seacă, Romania, Vaslui County

5. Letcani, Romania, Iași County; 6. Târgșor, Romania, Prahova County

7. Spanțov, Romania, Călărași County; 8. Olteni,

Romania, Teleorman County; 9. Kertchi, Ucraina

10. Brăviceni, Republic of Moldova; 11. Budești, Republic of Moldova 